\title{
A modification of the Daisy II - 220 technique for the determination of in vitro dry matter digestibility
}

M. de Figueiredo, A. Mbhele and J. Zondi

Dept of Agriculture, KwaZulu-Natal, P Bag X9059, Pietermaritzburg, 3200

\section{Introduction}

The digestibility value of a feed is one of the best indicators of nutritive value. In vivo determinations are expensive and time-consuming, rendering this technique impractical for routine analyses. In vitro determinations of digestibility using rumen fluid/cellulase have been used extensively in laboratories worldwide. These techniques use individual digestion containers shaken twice daily and a two-stage $48 \mathrm{~h}$ digestion. Due to the individual sample handling, filtration and washing steps performed, the introduction of human error and amount of time spent performing these steps are extremely high. The filter bag technology used in the Daisy apparatus involves enclosing the sample in a filter bag placed in a common rumen fermenter which can digest up to 100 samples at one time (compared with 40 in the conventional systems). This apparatus permits batch processing, removes the filtration step and maintain uniform heating with constant shaking. However, the use of the specially manufactured bags used in this technique makes the procedure expensive when analysing large quantities of samples. Furthermore, the determination of NDF as part of the procedure involves the use of a different apparatus for the completion of the analysis. In this study Daisy bags were compared with bags made of parachute and lining material. A comparison between $24 \mathrm{~h}$ and $48 \mathrm{~h}$ pepsin digestion and the replacement of NDF determination with the $24 \mathrm{~h}$ pepsin digestion was also evaluated.

\section{Material and Methods}

The reagents and procedure used in the Daisy II technique are reported in a companion abstract elsewhere in these proceedings. NDF was determined according to the Van Soest method. Bags measuring $5 \mathrm{x} 10 \mathrm{~cm}$ were made from parachute and lining material and heat-sealed. Acid pepsin solution (Minson \& McLeod, 1972) was prepared as follows: concentrated hydrochloric acid $(20 \mathrm{ml})$ was added to a $2000 \mathrm{ml}$ volumetric flask, half filled with distilled water and mixed well. Pepsin (activity, 1:10,000) $(2 \mathrm{~g})$ was added to the acid solution and the volume was made up to volume with distilled water. The final solution $(1600 \mathrm{ml})$ was added to each of the Daisy flasks.

\section{Results and Discussion}

The means $(\mathrm{n}=5)$ for dry matter digestibility of kikuyu, ryegrass, maize and eragrotis hay are presented in Table 1. No significant differences were observed between the different bags when maize and eragrotis hay were analysed. A significant $(\mathrm{P}<0.05)$ difference was observed for kikuyu between the Daisy and the lining bags and a highly significant $(\mathrm{P}<0.01)$ difference was found between Daisy and parachute bags for ryegrass. In terms of animal requirements, however, the difference observed for kikuyu is insignificant.

Table 1 Digestibility (\%) of feeds determined with the Daisy, parachute and lining bag techniques.

Level of significance

Daisy Parachute Lining Daisy vs Parachute Daisy vs Lining

\begin{tabular}{lccccc}
\hline Kikuyu grass & 70.72 & 69.44 & 73.44 & NS & NS \\
Ryegrass & 95.92 & 89.36 & 96.88 & & NS \\
Maize crop & 78.64 & 79.6 & 79.2 & NS & NS \\
Eragrotis hay & 42.32 & 41.04 & 40.96 & NS \\
\hline
\end{tabular}

The effect of a $24 \mathrm{~h}$ vs. $48 \mathrm{~h}$ pepsin digestion is shown in Table 2. Except for ryegrass, where the $24 \mathrm{~h}$ digestion gave significantly $(\mathrm{P}<0.01)$ higher values than the $48 \mathrm{~h}$ digestion, no significant difference was observed between $24 \mathrm{~h}$ and $48 \mathrm{~h}$ pepsin digestion. 
(C) South African Society of Animal Science

Short paper and poster abstracts: $38^{\text {th }}$ Congress of the South African Society of Animal Science

Table 2 Comparison of $24 \mathrm{~h}$ with $48 \mathrm{~h}$ pepsin digestion using the M\&M buffer.

\begin{tabular}{lllc}
\hline & $24 \mathrm{~h}$ pepsin & $48 \mathrm{~h}$ pepsin & Levels of significance \\
\hline Kikuyu grass & $57.76 \pm 1.689$ & $58.24 \pm 1.182$ & NS \\
Ryegrass & $88.24 \pm 0.685$ & $84.96 \pm 0.588$ & $* *$ \\
Maize crop & $89.72 \pm 1.525$ & $89.80 \pm 2.297$ & NS \\
Eragrotis hay & $37.26 \pm 1.906$ & $40.90 \pm 1.849$ & NS \\
\hline
\end{tabular}

The comparison between $24 \mathrm{~h}$ pepsin digestion and NDF determination for the dry matter digestibility of kikuyu grass, ryegrass, maize and eragrotis hay is presented in Table 3. A highly significant difference was observed between $24 \mathrm{~h}$ digestion and NDF determination for kikuyu grass and ryegrass, while there was no significance differences for maize and eragrotis hay.

Table 3 Comparison between $24 \mathrm{~h}$ pepsin digestion and NDF determination using the $\mathrm{M} \& \mathrm{M}$ buffer

\begin{tabular}{lccc}
\hline & 24 h pepsin & NDF & Levels of significance \\
\hline Kikuyu grass & $68.96 \pm 0.325$ & $72.16 \pm 0.531$ & \\
Ryegrass & $93.84 \pm 0.412$ & $89.76 \pm 0.786$ & \\
Maize crop & $76.56 \pm 0.349$ & $76.24 \pm 0.325$ & NS \\
Eragrotis hay & $40.50 \pm 1.135$ & $39.76 \pm 0.483$ & NS \\
\hline
\end{tabular}

\section{Conclusions}

Lining bags can economically replace the Daisy bags (R0.03 vs R3.00). Although there are reports that a one percent digestibility difference can affect milk yield, bigger variations in the digestibility of kikuyu and ryegrass between and within sheep were observed in a digestibility trial reported by Figueiredo et al (see elsewhere in these proceedings) than that found when $24 \mathrm{~h}$ pepsin replaced the NDF determination and $24 \mathrm{~h}$ pepsin digestion was used instead of $48 \mathrm{~h}$ digestion.

\section{References}

Minson, D.J. \& McLeod, M.N., 1972. Division of Tropical Pastures Technical Paper No. 8, Commonwealth Scientific and Industrial Research Organization, Australia.

Van Soest, P.J., 1963. J. Assoc. Off. Agr. Chem. 46, 829. 